\title{
Description of the first Palaearctic species of Tineobius Ashmead, 1896 with DNA data, a checklist of world species, and nomenclatural changes in Eupelmidae (Hymenoptera, Chalcidoidea)
}

\author{
Lucian FUSU $1,{ }^{*} \&$ Antoni RIBES ${ }^{2}$ \\ ${ }^{1}$ Alexandru Ioan Cuza University, Faculty of Biology, Bd. Carol I no. 11, 700506, Iasi, Romania. \\ ${ }^{2}$ Deceased 2 Dec. 2014. Former address: C/Lleida 36, 25170 Torres de Segre, Lleida, Spain. \\ *Corresponding author: lucfusu@hotmail.com \\ ${ }^{1}$ urn:Isid:zoobank.org:author:894051B1-3121-4F10-90F5-A6E2284A7123 \\ ${ }^{2}$ urn:Isid:zoobank.org:author:98B51D2C-3663-4382-BB10-C2DD8D1E80CC
}

\begin{abstract}
Tineobius (Tineobius) tamaricis Ribes \& Fusu sp. nov. is newly described from Parapodia sinaica (Frauenfeld, 1859) (Lepidoptera, Gelechiidae) galls from Catalonia in Spain. This is the first record of the so far Palaeotropical genus Tineobius Ashmead, 1896 in the Palaearctic region. Basic biological data and a DNA barcode are provided for the new species. Parapodia sinaica (the host of T. tamaricis sp. nov.) is reported for the first time to form galls on Tamarix canariensis (Willd). A checklist of described world Tineobius species is provided, with nine species formally transferred to Tineobius from Anastatoidea Gahan, 1927 and thirteen species newly assigned to T. (Tineobius). Metapelma seyrigi (Risbec, 1952) is transferred to Tineobius and the replacement name Tineobius (Tineobius) madagascariensis nom. nov. is proposed, as the name is preoccupied by Tineobius (Tineobius) seyrigi (Ferrière, 1938) comb. nov.; Tineobius (Tineobius) albopalpalis (Brues, 1907) comb. nov. is transferred from Charitopus Förster, 1856 (a genus in Encyrtidae). One species is transferred from Anastatoidea to Eupelmus Dalman, 1820 as Eupelmus (Episolindelia) ambatomangae (Risbec, 1958) comb. nov.
\end{abstract}

Keywords. Chalcidoidea, DNA barcoding, Tamarix, nomenclature, Parapodia sinaica.

Fusu L. \& Ribes A. 2017. Description of the first Palaearctic species of Tineobius Ashmead, 1896 with DNA data, a checklist of world species, and nomenclatural changes in Eupelmidae (Hymenoptera, Chalcidoidea). European Journal of Taxonomy 263: 1-19. http://dx.doi.org/10.5852/ejt.2017.263

\section{Introduction}

Tineobius Ashmead, 1896 (Chalcidoidea Latreille, 1817; Eupelmidae Walker, 1833; Eupelminae Walker, 1833 ) is a Palaeotropical genus known so far from the Afrotropical, Oriental, and Australasian ecozones (Gibson 1995), and never reported from the Palaearctic region. Tineobius is currently divided into three subgenera (Gibson 1995), and known members are ectoparasitoids of Lepidoptera and of their primary parasitoids: Ichneumonidae (Gahan 1927), Braconidae (Ferrière 1936, 1938) and Tachinidae (Bouček 1988). 
Most species of Tineobius were revised by Ferrière (1938) as Anastatoidea Gahan, 1927. After Ferrière's revision further species were described by Risbec in Anastatoidea, who also published a new key to the Afrotropical species (Risbec 1952, 1958), but out of four species described by this author two belong to Eupelmus (Episolindelia) Girault, 1914 (Fusu et al. 2015 and present paper). Yoshimoto \& Ishii (1965) described two further species in Anastatus Motschulsky, 1859 (Gibson et al. 2012) and Bouček (1988) one species in Duanellus Bouček, 1988. The latter author synonymized Anastatoidea with Tineobius, transferring to Tineobius all the Australian species described by A.A. Girault and some of the species described by C. Ferrière (Bouček 1988), but many of Ferrière's species were never formally transferred to Tineobius. According to Bouček (1988) and Gibson (1995), more undescribed species are known, but all are Palaeotropical. We report here on the unexpected discovery of the first species of Tineobius in the Palaearctic region.

\section{Material and methods}

Specimens of a species of Tineobius (Tineobius) were found in Spain near Lleida during a survey of the Chalcidoidea of the region by AR. The first specimens emerged in 2008 from Parapodia sinaica (Frauenfeld, 1859) (Lepidoptera, Gelechiidae) galls on Tamarix canariensis, in a small number compared to other parasitoids. Further galls were collected from 2010 to 2013, stored indoor in polythene bags, controlled by AR for condensation and fungal growth, and checked periodically for the emerged chalcid wasps. Other gall samples were dissected for further biological observations.

Emerged specimens were either killed with ethyl acetate or placed directly in ethanol. Those in ethanol were dried using HMDS (Heraty \& Hawks 1998) before mounting on cards or points. The majority of the specimens were measured by AR with a stereomicroscope with a maximum magnification of $90 \times$, fitted with a $10 \mathrm{~mm}$ ocular grid having 100 divisions. For paratype no. 10077 measurements were made by LF with an Olympus SZX9 stereomicroscope fitted with a $10 \mathrm{~mm}$ ocular grid having 100 divisions; to reduce glare, a double piece of tracing paper was inserted between the light source and the specimen. The habitus photograph of the holotype and acropleuron of paratype no. 13940 were taken by AR with a compact digital camera placed over the trinocular stereo microscope and the specimen illuminated with a 144-LED ring as a light source. The serial images were combined using CombineZ5 software (Alan Hadley, http://www.bioinfo.org.uk/html/b148461.htm). All other photographs were taken by LF with a Leica DFC 500 digital camera attached to a Leica M205 A motorized stereomicroscope and the specimen illuminated within a cylinder made of white expanded polystyrene with an Olympus KL1500 LCD and a Kruss 150-watt light source. The serial images were combined with Zerene Stacker (Zerene Systems LLC, http://www.zerenesystems.com/) and digitally retouched using Adobe Photoshop.

Specimens of the type series were labelled by LF using the data provided earlier by AR. The original labels contained only a catalogue number referring to an electronic database by AR that is currently inaccessible. These catalogue numbers are used throughout the text to uniquely designate a specimen and are provided in the material examined section after the name of the collector. The catalogue numbers were confidently correlated with collecting data in all cases except for paratypes 13940 and 22575 for which data could have been reversed. Data from different labels of the holotype are separated in text by a slash. Within the checklist of described world species of Tineobius provided at the end of this paper, the species are listed alphabetically within the three subgenera.

Most morphological terms follow Gibson (1995, 1997), wing folds terminology Gibson (2004), and sculpture categories as defined in Al Khatib et al. (2014) and Gibson \& Fusu (2016) except mesoscutellum is used instead of scutellum and metascutellum instead of dorsellum in accordance with the recommendations of the Hymenoptera Anatomy Ontology Portal (Yoder et al. 2010). 


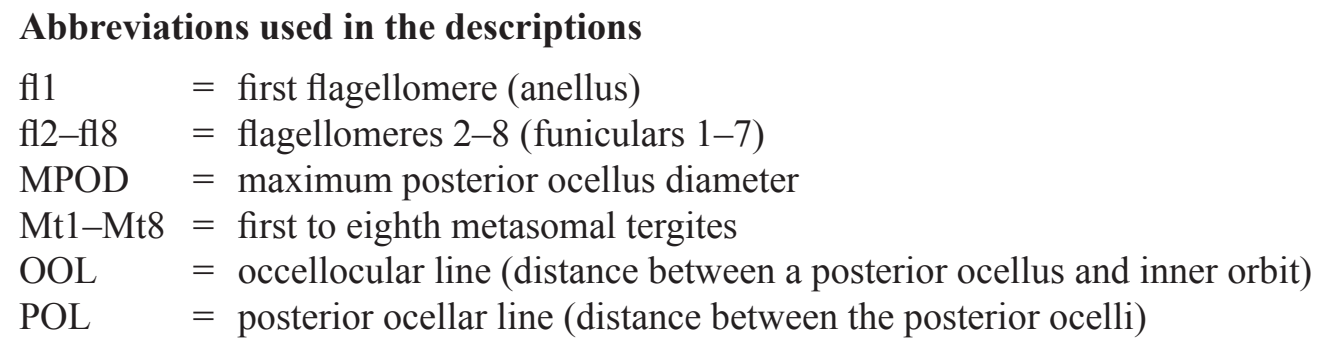

For the molecular analyses DNA was initially extracted by LF from non-type specimens 22591 and 22592 using a non-destructive protocol based on the DNeasy ${ }^{\circledR}$ blood and tissue kit (Qiagen, Hilden, Germany) as described in Polaszek et al. (2014). Because no PCR product was obtained, DNA was subsequently extracted from the left mid and hind legs of the holotype using a Chelex resin based protocol that was successfully used on other chalcid wasp taxa (Gebiola et al. 2009; 2015). After DNA extraction, the legs were dried with HMDS and glued back to the specimen. We used an extraction protocol that avoids the boiling of the sample, as suggested by Casquet et al. (2012). This result in double stranded DNA that is much more stable during manipulations and for long term storage compared to the single stranded DNA obtained with an extraction protocol that uses a final heating step at $95^{\circ}$ or $100^{\circ} \mathrm{C}$ to inactivate the protease. Briefly, the modified protocol is as follows. Legs including coxae are placed in $25 \mu \mathrm{l}$ of $5 \%$ Chelex ${ }^{\circledR} 100$ (Bio-Rad Laboratories) in a $1.5 \mathrm{ml}$ microtube and proteinase $\mathrm{K}$ is added last $(1.65 \mu \mathrm{l}$ of $600-1000 \mathrm{u} / \mathrm{ml}, 14-22 \mathrm{mg} / \mathrm{ml})$. If whole specimens are used, volumes are doubled. The tubes are incubated at $56^{\circ} \mathrm{C}$ for $5-6$ hours. After the digestion, the microtubes are centrifuged briefly and the supernatant is directly used as template in a PCR. The standard barcode region (Hebert et al. 2003) was amplified by PCR using the primer pair LCO1490 / HCO2198 (Folmer et al. 1994). A standard $25 \mu \mathrm{l}$ PCR was performed, containing $2.5 \mu \mathrm{l}$ of $10 \times$ PCR buffer, $1 \mu \mathrm{l}$ of $50 \mathrm{mM} \mathrm{MgCl}, 0.5 \mu \mathrm{dNTPs}$ solution $(10 \mathrm{mM}$ each), $1.25 \mu \mathrm{l}$ of each primer $(10 \mu \mathrm{M}), 1.25 \mu \mathrm{l}$ Taq polymerase $(1 \mathrm{u} / \mu \mathrm{l}$, Red Taq DNA Polymerase, Rovalab), $4 \mu$ DNA extract, and PCR grade water to final volume. PCR conditions were: $94^{\circ} \mathrm{C}$ for $2 \mathrm{~min}$, followed by 40 repeated cycles of $94^{\circ} \mathrm{C}$ for $30 \mathrm{~s}, 42^{\circ} \mathrm{C}$ for $60 \mathrm{~s}$ and $72{ }^{\circ} \mathrm{C}$ for $35 \mathrm{~s}$, a final extension at $72^{\circ} \mathrm{C}$ for $5 \mathrm{~min}$, and incubation at $10^{\circ} \mathrm{C}$. The $\mathrm{PCR}$ products were visualized on a $1 \%$ agarose gel. Both DNA strands were sequenced at Macrogen Europe (Amsterdam) using the same primers used for the PCR. Sequence verification was conducted by comparing forward and reverse chromatograms using Pregap4 v1.5 and Gap v4.10 in the Staden Package (Bonfield et al. 1995).

\section{Abbreviations used for repositories}

AICF $=$ Al. I. Cuza University, Iaşi, Romania, Lucian Fusu collection
ANIC $=$ Australian National Insect Collection, Canberra, Australia
ARPC $=$ Antoni Ribes personal collection, Lleida, Spain [deposited in BMNH]
BMNH $=$ The Natural History Museum, London, U.K.
BPBM $=$ Bernice Pauahi Bishop Museum, Honolulu, Hawaii
MNCN $=$ Museo Nacional de Ciencias Naturales, Madrid, Spain
MNHN $=$ Muséum national d'Histoire naturelle, Paris, France
MPMW $=$ Milwaukee Public Museum, Milwaukee, Wisconsin, U.S.A.
QMBA $=$ Queensland Museum, Brisbane, Australia
RRAC $=$ Richard R. Askew collection, Beeston, Cheshire, U.K.
USNM $=$ United States Museum of Natural History, Washington D.C., U.S.A.




\title{
Results
}

\author{
Class Hexapoda Blainville, 1816 \\ Order Hymenoptera Linnaeus, 1758 \\ Suborder Apocrita Latreille, 1810 \\ Superfamily Chalcidoidea Latreille, 1817 \\ Family Eupelmidae Walker, 1833 \\ Subfamily Eupelminae Walker, 1833 \\ Genus Tineobius Ashmead, 1896
}

\section{Diagnosis}

Females can be recognized by the following combination of characters: vast majority of species with a conspicuously lengthened maxillary palpus with apical palpal segment elongate, distinctly curved or with inner margin angulate basally, prepectus with light-coloured and large frontal surface, propodeum with transverse plical depression and either with membranous white spot or line within depression (nominal subgenus and Duanellus) or with whitish membranous bottom (in T. (Progenitobius) Gibson, 1995), mesotibia without oblique apical groove, gaster with deeply emarginate syntergum and very long and filamentous ovipositor sheaths (Gibson 1995). Excluding some T. (Progenitobius), metatibia conspicuously compressed with laminate dorsal margin and white along lamina or at least dorsobasally, with the exception of some T. (Duanellus).

Tineobius (Tineobius) tamaricis Ribes \& Fusu sp. nov. urn:1sid:zoobank.org:act:DFECB6FA-96D1-4EDA-B742-85D7DA57E85C

Fig. 1A-H

\section{Etymology}

Named from its associated plant, Tamarix canariensis (Willd.). A noun in the genitive case.

\section{Type material examined}

Holotype

SPAIN: q, Torres de Segre, Pantà de Camelis (Lleida), 31T BG80, 160 m, Leg. A. Ribes, 22576 / Parapodia sinaica galls on Tamarix canariensis, col. 30.i.2013, em. 2013, A. Ribes, 22576 / HOLOTYPUS + Tineobius (Tineobius) tamaricis Ribes \& Fusu Det. Fusu L. 2015. Original label: Tineobius, Tamarix, Torres,, , 22576. DNA voucher label: DNA extracted, 15.vii.2015 Fusu, Tt.SP 03 (BMNH; BM Hym Type 5.4849, barcode number NHMUK010264039). Condition: entire, uncontorted, glued by right side and wings to a card point.

\section{Paratypes}

SPAIN: 4 q , same data as holotype, except galls collected 17 Oct. 2012, emerged 2013 (no. 22575?) (1 q BMNH); galls collected 13 Feb. 2010, emerged 2010 (no. 13940?) (1 q MNCN); 31T BF99, $140 \mathrm{~m}$, galls collected on 20 Oct. 2007, emerged in 2008 (no. 10077) (1q AICF); galls collected 13 Feb. 2010, emerged 2010 (no. 22662) (1 + with gaster missing, RRAC).

\section{Additional material examined}

SPAIN: 2 우, same data as holotype, except galls collected 8 Jan. 2011, emerged 22 Aug. 2011 (no. 22591), and DNA voucher label: DNA extracted, 12.vi.2014 Fusu, Tt.SP 01 (1 q, damaged, head and metasoma chowed by psocids, ARPC); galls collected 25 Jan. 2012, inside galls 2013 (no. 22592), and DNA voucher label: DNA extracted, 15.vi.2014 Fusu, Tt.SP 02 (1 q, damaged and slightly mouldy, not emerged, antennae missing, with the head capsule of the host in a gelatine capsule on the same pin, ARPC). 


\section{Description}

Female (Fig. 1A, C)

LENGTH. 2.2-3.5 $\mathrm{mm}$ (about 3.2-6.3 $\mathrm{mm}$ including ovipositor); holotype $3.3 \mathrm{~mm}$ (about $6 \mathrm{~mm}$ including ovipositor).

CoLour. Head dark, with faint multicoloured metallic reflections on frontovertex and occiput changing colour and intensity depending on viewing angle and lighting conditions ( $c f$. heads in Figs 1A and 1C); more conspicuously metallic blue to greenish-blue variably extensively along eye orbit, in front of anterior ocellus and near posterior ocelli; interantennal region, scrobal depression and parascrobal region with green, bronze, coppery and violet reflections; lower face, gena and temple dark blue with some violet, greenish and bronze reflections. Maxillary and labial palps dark brown. Scape pale reddish to orangish brown, pedicel and flagellum dark brown. Mesosoma including pronotum (Fig. 1B, G) mainly similar in colour to frontovertex except as follows. Mesoscutum dark blue to violet with green to coppery lustre more conspicuously on anteromedial convex lobe. Axillae and about anterior half of mesoscutellum reddish to orangish brown with at most with faint metallic lustre, mesoscutellum progressively darker posteriorly with frenal area dark green with multicoloured metallic lustre. Acropleuron (Fig. 1A-C) reddish to orangish brown in posterior half to two-thirds and dark, mostly metallic bluish-green, anteriorly. Tegula and prepectus dark reddish-brown, the frontal surface of prepectus dirty yellowish only in inferior third. Metanotum and callar region of propodeum dark with blue reflections. Legs reddish to orangish brown. Front leg almost uniformly reddish-brown beyond coxa, except femur darkened on posterior surface. Middle leg similar in colour to front leg, except femur and tibia somewhat darkened dorsally, anterodorsal angle of femur with a whitish spot, and mesotibial spur brown; mesotarsus with basal two tarsomeres dirty-white except yellowish ventrally and apically and subsequent tarsomeres gradually darker with apical tarsomere distinctly brown. Mesotibial pegs reddish-brown, similar in colour to apex of tibia and mesotarsal pegs pale basally and brownish apically. Hind leg with femur reddish to orangish brown dorsally and metallic brown ventrally to almost uniformly reddish-brown; tibia reddish-brown, with laminated dorsal margin yellowish-white; tarsus reddish-brown. Gaster dark, with faint metallic lustre except basal tergite (Mt2) dorsally with obvious bluish-green to bronze reflections subbasally. Ovipositor sheaths dark brown, ventrally with a narrow, yellowish to orangish band along length, broadening subapically into an indistinctly delimited and dorsally incomplete pale ring.

HeAD. In dorsal view $1.8-1.95 \times$ as wide as long, $1.1-1.15 \times$ as wide as mesoscutum, and temples $0.22-0.35 \times$ eye length; with interocular distance $0.31-0.34 \times$ head width. Ocelli in a right-angled triangle with POL 4.1-4.5 $\times$ OOL and OOL 0.4-0.43 $\times$ MPOD. Eyes 1.4-1.5 $\times$ as long as broad, with short sparse pilosity, inner eye orbits converging upwards. Head in frontal view $1.15-1.2 \times$ as broad as high, with dorsal margin of torulus in line with or slightly above lower orbit. Malar space $0.5-0.55 \times$ eye height, malar sulcus slightly out curved, mouth opening 1.4-1.6 $\times$ as broad as malar space. Scrobal depression wide, about as broad as high, extending up to half eye height, carinately margined laterally at least in basal two thirds. Vertex transversely reticulate-imbricate, frons conspicuously reticulate, with mesh size about as large as an ommatidium; scrobal depression including scrobes distinctly reticulate to transversely reticulate-rugulose. Lower face, interantennal region and parascrobal regions with white, slightly lanceolate setae compared to thinner, more hair-like, dark setae on frontovertex. Setae along outer orbit comparatively dense, white, slightly lanceolate and directed toward orbit, those along inner orbit and upper occiput long and semierect (Fig. 1E, G). Maxillary palpus enlarged, the last segment slightly curved and nearly as long as ventral length of mandible. Antenna (Fig. 1D) with scape 6-6.5 $\times$ as long as broad and 0.9-0.95 $\times$ eye length, not reaching to anterior ocellus. Pedicel plus flagellum $1.43-1.5 \times$ head width; pedicel in dorsal view $2.2-2.7 \times$ as long as broad, $1.9-2.1 \times$ as long as fl1 (anellus), and $0.45-0.55 \times$ as long as combined length of fl1 and fl2. Flagellum basally narrower than pedicel, the funiculars shorter and slightly wider distally; fl1 elongate, $1.4-1.7 \times$ as long as broad; fl2 the 

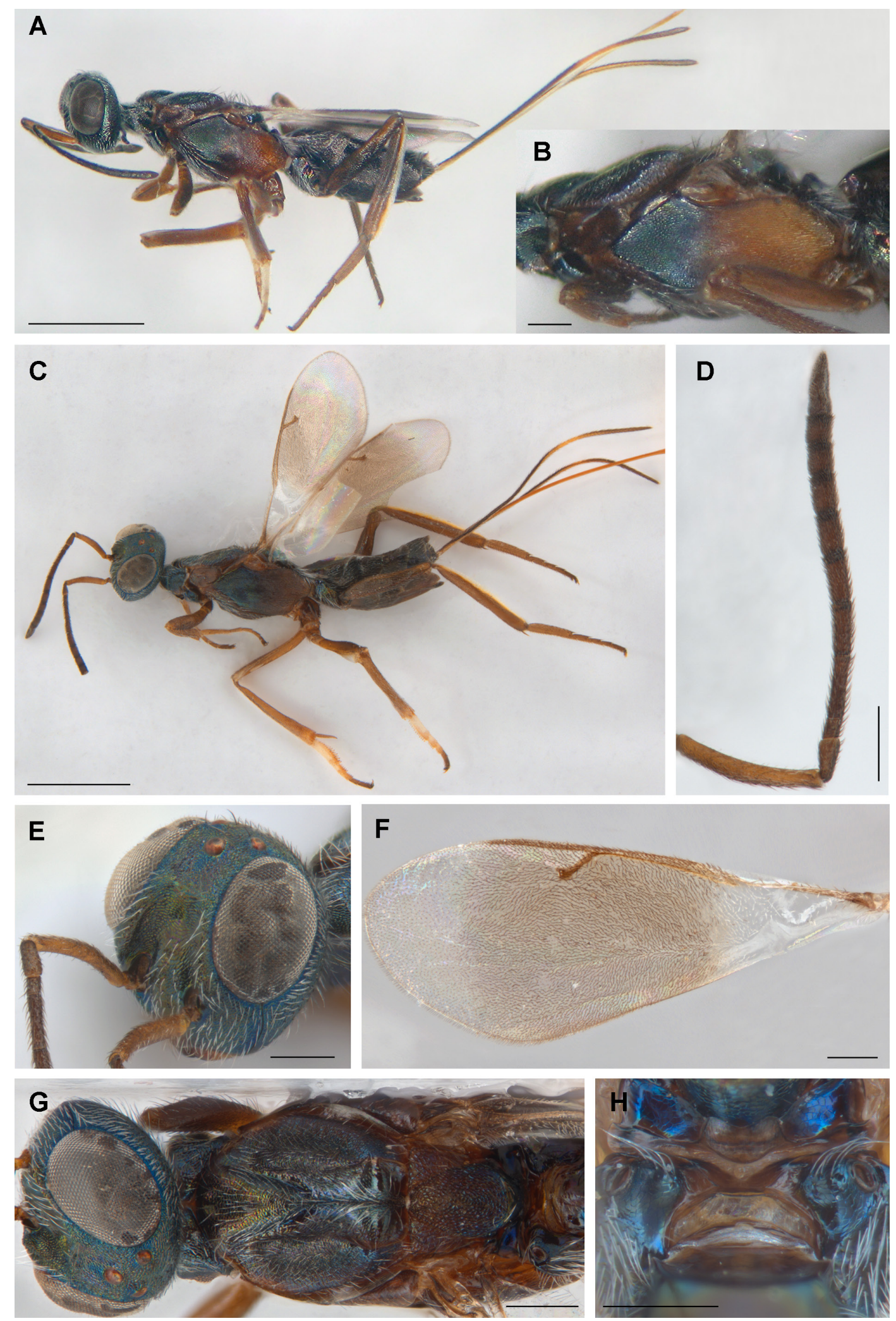

Fig. 1. Female of Tineobius (Tineobius) tamaricis Ribes \& Fusu sp. nov. A. Habitus of holotype before card mounting. B. Mesosoma (paratype 13940). C-G. Paratype 10077. C. Habitus. D. Antenna. E. Head. F. Fore wing. G. Head and mesosoma, dorsal view. H. Metanotum and propodeum (paratype 13940). Scale bars: A, C $=1 \mathrm{~mm}$; B, D-H $=0.2 \mathrm{~mm}$. 
longest segment, $4.1-4.6 \times$ as long as broad and $1.15-1.25 \times$ as long as fl3; fl3 to fl8 2.85-3.5, 2.35-2.7, $1.75-2.15,1.45-1.9,1.3-1.5$, and $1.15-1.25 \times$ as long as broad respectively; clava $2.0-2.35 \times$ as long as broad.

Mesosoma (Fig. 1G). Elongate, in dorsal view 2.0-2.05 $\times$ as long as broad. Pronotum $0.30-0.35 \times$ as long as mesoscutum, divided medially. Anteromedial mesoscutal lobe 1-1.1 $\times$ as long as broad, lateral lobes markedly elevated; mesoscutum imbricate-reticulate with sculpture more superficial than on head, transversely imbricate-reticulate anteriorly, reticulate on depressed area behind anteromedial lobe, and with effaced sculpture posteriorly in front of mesoscutellum; with comparatively inconspicuous setae anteriorly and on lateral lobes, but with long, white conspicuous setae on bottom of median depressed area. Mesoscutellar-axillar complex $0.9-1.05 \times$ as long as broad, $0.53-0.6 \times$ as long as mesoscutum, with isodiametric reticulate sculpture, coarser than on mesoscutum; frenal area differentiated by smoother, alutaceous-imbricate sculpture and sharply declivitous; mesoscutellum with sparse, erect black setae anterodorsally, and short suberect pale setae near frenal area. Propodeum with deep plical depression with whitish membranous bottom and a differentiated whitish spot (Fig. 1H) (exact structure often not visible, being overlaid by metascutellum, Fig. 1G); callar region convex, outer half covered with dense, long white setae and inner half abruptly sloping from spiracle to plical depression, with a smaller tuft of long white setae; spiracle oval, situated on outer side of callus (Fig. 1H). Acropleuron (Fig. 1B) reticulate in anterior third and ventrally, and in posterior third reticulate to striate with strongly elongated cells. Mesotibia with 3-6 apical pegs in 1 or 2 rows; basitarsus ventrally with 10-15 pegs in row on each side, second tarsomere with 4-5, third with 3-5, and fourth with 3-4 pegs in row on each side. Metatibia and metabasitarsus compressed, metatibia $4.9-5.7 \times$ as long as broad, with laminate dorsal margin.

Fore wing (Fig. 1F) 2.5-2.6 $\times$ as long as broad, broadly infuscate medially and very narrowly at extreme base, hyaline below submarginal vein and parastigma and apically beyond venation; with relatively long and thick, dark, hair-like setae in infuscate regions, and with very short and fine but dark setae in apical hyaline portion; basal hyaline region with a band of pale setae behind basal half of parastigma and apex of submarginal vein. Basal cell variably extensively setose with pale setae, sometimes mostly bare but at least bare mesally and with setae sparser than on disk, open posteriorly because mediocubital fold, cubital and vanal areas bare. Costal cell $8.5-9.5 \times$ as long as broad, $1.3-1.35 \times$ as long as marginal vein, dorsally near leading margin with row of dark setae in about basal half but bare in front of parastigma, ventrally with two rows of pale setae along length except more extensively setose basally. Marginal vein $2.9-3.3 \times$ as long as stigmal vein. Stigmal vein nearly straight, stigma broadened with uncus slightly shorter than stigmal vein breadth. Postmarginal vein $2.4-2.55 \times$ as long as stigmal vein, and $0.75-0.85 \times$ as long as marginal vein.

Gaster (excluding ovipositor sheaths) $0.85-0.9 \times$ as long as mesosoma and $1.9-2.15 \times$ as long as broad, with white setae mostly laterally, long and suberect on first tergite and shorter and more adpressed on rest. Mt2 deeply incised, surface superficially coriaceous-imbricate to reticulate-imbricate; following tergites with similar but stronger sculpture, posterior margin of Mt3 to Mt5 sinuately emarginate, that of Mt6 straight and Mt7 slightly angulate posteriorly. Mt7 of about same length as Mt6 (concealed in various degrees under Mt6 in all available specimens). Ovipositor sheaths about 1.9-2 $\times$ length of gaster, $0.8-0.9 \times$ body length, and 2.3 $-2.4 \times$ length of metatibia, the pale portion about $1.5 \times$ as long as the apical dark portion.

\section{Male}

Unknown.

\section{Distribution}

Spain. 


\section{Remarks}

Tineobius tamaricis sp. nov. is placed within Tineobius s. str. because the female possess the following combination of characters: head in lateral view comparatively flat, with a band of differentiated reflective setae along outer orbit; fl2 not anelliform, much longer than fl1 or pedicel; metascutellum only slightly protuberant over propodeal plical depression; plical depression with a whitish membranous bottom and a differentiated anteromedian whitish spot; metatibia compressed with laminated dorsal margin yellowish-white; Mt6 with posterior margin straight and Mt7 transverse and of about the same length as Mt6. Females of T. (Duanellus) share the same presumably derived state of the head, propodeum, metatibia and metasoma, but antennae are inserted near the centre of the face with fl2 anelliform and similar to fl1 (Bouček 1988: figs 1011, 1013) and outer orbit lacks a band of spatulate or lanceolate setae (Gibson 1995). The three known species of T. (Progenitobius) of which one is undescribed (Gibson 1995; Fusu et al. 2015) all have a subglobose head (Fusu et al. 2015: fig. 3C), Mt6 with a broadly and deeply emarginate posterior margin similar to other tergites, and Mt7 longer than Mt6 and subtriangular. Also, the two described species, both from Madagascar, do not have a carinately compressed metatibia though basal part of dorsal margin is whitish (Gibson 1995; Fusu et al. 2015). However, one undescribed species from South Africa is atypical for the subgenus in having a metatibia similar to that found in most species of Tineobius s. str. (Gibson 1995). The distribution of the character states within the genus and the potential paraphyly of $T$. (Progenitobius) relative to Tineobius s. str. $+T$. (Duanellus) were discussed in detail by Gibson (1995).

Using Ferrière (1938) and Risbec (1952) keys, the holotype of T. tamaricis sp. nov. runs near T. indicus (Ferrière, 1938) and T. philippinensis (Ferrière, 1938) comb. nov. because of the following combination of features: ovipositor sheaths with pale subapical band, fore wing with infuscate median area and sparse setation basally, mesosoma with some reddish to orangish brown parts in addition to the acropleuron, and metafemur mostly brown. It differs from these species by a different combination of colour characters, setation of wing disc, and proportion of antennal segments. Tineobius tamaricis sp. nov. differs from T. indicus, a species from Pakistan, in having reduced orangish brown areas (mesoscutum and gaster entirely dark, metallic), metatarsus dark brown, fore wing without spatulate setae, fl2 $1.35-1.65 \times$ as long as pedicel, and ovipositor sheaths almost as long as gaster plus mesosoma. Tineobius indicus (holotype in BMNH examined) differs by the following: front leg including coxa, as well as prepectus, and acropleuron except anteriorly, brownish-orange; mesoscutum brownish-orange except posterior median depressed area and posterior half of median and lateral lobes dark with some metallic lustre; mesoscutellum and axillae orange; first and second gastral tergites pale, yellowish-brown; metatarsus with first and last tarsomeres brown, second paler, and third and fourth pale yellowish; fore wing with short, stout and spatulate setae below parastigma, marginal and stigmal veins; fl2 about as long as pedicel and ovipositor sheaths as long as gaster plus half of mesosoma. Tineobius tamaricis sp. nov. differs from T. philippinensis (holotype in BMNH examined), a species from Philippines, in having the pronotum dark metallic, a reddish to orangish brown scape, head without conspicuously modified setae, reticulate frontovertex, scrobal depression as broad as high, fore wing without lanceolate setae, and ovipositor sheaths $0.8-0.9 \times$ as long as rest of body. Tineobius philippinensis has the following: lateral panel of pronotum anteriorly and posteriorly, prepectus, posterior half of acropleuron, base of mesoscutellum and axillae reddish-brown; scape brown and only slightly paler than flagellum; head with a tuft of long, black, lanceolate setae at boundary of vertex and occiput and very long erect setae on frontovertex; frontovertex virtually polished, with effaced coriaceous sculpture; scrobal depression strongly transverse, $\Pi$-shaped and widely separated from anterior ocellus; fore wing with lanceolate to spatulate setae below parastigma and marginal vein; and ovipositor sheaths $0.5 \times$ as long as rest of body.

One paratype of $T$. tamaricis sp. nov. has all the parts that have a noticeable reddish hue in other specimens (Fig. 1A-B) more inconspicuously differentiated in colour, dark reddish-brown (Fig. 1C, G), and therefore in available keys runs to the Afrotropical species T. afer (Ferrière, 1938) comb. nov. and 
T. montanus (Ferrière, 1938) comb. nov. (type material in BMNH examined). Specimens of T. tamaricis sp. nov. with this colour pattern differ most conspicuously from $T$. afer in having a slenderer antenna, with fl 2 more than $4 \times$ as long as broad and longer than pedicel, fore wing with hair-like setae behind marginal vein, and scrobal depression carinate laterally. In T. afer fl 2 is $2 \times$ as long as broad and slightly shorter than pedicel, fore wing with spatulate setae behind parastigma and basal $2 / 3$ of marginal vein, and scrobal depression only slightly impressed, about as long as wide, and almost touching inner eye orbit. From $T$. montanus it differs in having a shorter fll and in the structure of fore wing setation and scrobal depression. In T. montanus fl 1 is about $2 \times$ longer than broad, and the fore wing and scrobal depression are as described for $T$. afer.

In having only hair-like setae on fore wing, T. tamaricis sp. nov. is similar to T. lamborni (Ferrière, 1938) comb. nov. (holotype in BMNH examined) described from sub-Saharan Africa (Malawi), but this species differs in having the pedicel only $1.3 \times$ as long as fl 1 and about $0.5 \times$ as long as $\mathrm{fl} 2$, a brown scape only slightly paler than flagellum, a narrow $\Lambda$-shaped scrobal depression carinately margined laterally along entire length except dorsally below anterior ocellus and separated from anterior ocellus by only about one ocellar diameter; body mostly dull, black with very reduced metallic lustre; fore wing base without band of pale setae behind parastigma, and bare except about basal half of basal cell with scattered dark setae.

\section{DNA barcoding}

A complete DNA barcode sequence was obtained from the holotype and was deposited on GenBank under the accession number KT962861. Because this is the first DNA barcode of a Tineobius species, a Blast search (Altschul et al. 1990) in GenBank revealed high similarities with Cecidostiba Thomson, 1878 (Pteromalidae) and Eupelmus Dalman, 1820 (Eupelmidae) sequences, but at least this attests that it is a genuine Chalcidoidea sequence and not one from a contaminant or an endosymbiont.

\section{Ecology}

Tineobius tamaricis sp. nov. is a parasitoid of Parapodia sinaica larvae that form galls on Tamarix twigs. These galls are known so far from Egypt (Houard 1912), Iran (Rezaei et al. 2007), Israel (Gerling et al. 1976), and France (Joannis 1912, as P. tamaricicola Joannis, 1912; Dauphin \& Aniotsbehere 1994). Parapodia sinaica produces galls on several Tamarix species including T. africana Poir., T. gallica L., T. tetragyna Ehrenb., T. nilotica (Ehrenb.) Bunge, and T. jordanis Boiss. To the best of our knowledge, it was not recorded previously from Spain or on T. canariensis (new host record). The galls are similar to those of Amblypalpis olivierella (Ragonot, 1886) reported by Gerling et al. (1976), another Gelechiidae moth galling several Tamarix species, but differ in being smaller in size (12-13 $\times 6-8 \mathrm{~mm})$, having a fusiform shape, and the cavities inside the gall leaving the central column of the vascular bundles intact. Adult moths have the fore wings pale greyish brown, with a dark and pale spotted pattern. In the survey of parasitoids in Tamarix galls in Lleida, a number of parasitoids were found in the galls, the most common being a species of Apanteles sp. (Braconidae: Microgastrinae), of which 186 specimens emerged, and occasionally other parasitoids of Braconidae, Ichneumonidae, Eulophidae, Eupelmidae and Pteromalidae (a paper concerning this parasitoid complex is in preparation). A small number of T. tamaricis sp. nov. females emerged from the galls, with a total of six specimens over four years and one specimen (on one occasion two) per year. It therefore is not a common species, but with a stable population in this stand of Tamarix in this locality. Emergence dates of T. tamaricis sp. nov. adult females were not clearly established, but possibly between June and August, as they were found dry in the rearing bags during this period, after the usual emergence dates between May and June of the lepidopteran host and most of their parasitoids. From one sample of galls collected on 25 Jan. 2012, and after the emergence period finished with no Tineobius emerging, in one of the galls opened on 15 Mar. 2013 an adult female was found inside as it was unable to emerge, and near the wasp there were the remains of a consumed $P$. sinaica larva, including its cephalic capsule. Parapodia sinaica larvae 
usually bore an exit hole in the wall of the woody gall before pupation, partly closed by the epidermis of the gall, and some other parasitoid species were also found dead inside galls, unable to complete the hole for exiting. We interpret this finding as evidence for the $P$. sinaica larva being the host. In this case, T. tamaricis sp. nov. was either a primary parasitoid or, more likely, a hyperparasitoid via Apanteles sp., because other species of Tineobius with known biology are reported as primary and often as secondary parasitoids of Lepidoptera (Gahan 1927; Ferrière 1936, 1938). For example, the type series of Tineobius seyrigi (= Anastatoidea seyrigi) $(\mathrm{MNHN})$ is accompanied by a large moth cocoon of about 33 by $16 \mathrm{~mm}$ with the label: "obtenu d'éclosion de Prospilus / cohacarum m. (i. litt.) sur / Borocera sp. - sur 500 cocons, / seuls ceux qui contenaient des / Prospilus, étaient parasités par l'Eupelmid" [obtained by rearing from Prospilus cohacarum mihi (in litteris) on Borocera sp. - out of 500 cocoons only those containing Prospilus were parasitised by the eupelmid] (see also Ferrière 1936).

\section{Checklist of described world species of Tineobius \\ Tineobius (Duanellus) Bouček, 1988}

Duanellus Bouček, 1988: 566, figs 1011-1013. Type species: Anastatoidea jacobsoni Ferrière, 1938 by original designation. Synonymy by Gibson (1995: 284).

\section{Tineobius (Duanellus) facialis (Bouček, 1988)}

Duanellus facialis Bouček, 1988: 566-567, figs 1012-1013. Holotype + , by original designation (ANIC, not examined). Type locality: Australia, Queensland, 14 km NW Hope Vale Mission.

Tineobius (Duanellus) facialis - Gibson 1995: 286.

\section{Tineobius (Duanellus) jacobsoni (Ferrière, 1938)}

Anastatoidea jacobsoni Ferrière, 1938: 50-52, 57, fig. 7. Holotype + , unique specimen (BMNH 5.942, examined by LF). Type locality: Sumatra, Fort de Kock.

Anastatoïdea jacobsoni - Risbec 1952: 67 (catalogued).

Duanellus jacobsoni - Bouček 1988: 566, fig. 1011.

Tineobius (Duanellus) jacobsoni - Gibson 1995: 286.

Tineobius (Progenitobius) Gibson, 1995

Tineobius (Progenitobius) Gibson, 1995: 286-287, fig. 452. Type species: Anastatoidea elongata Risbec, 1952 by monotypy and original designation.

\section{Tineobius (Progenitobius) elongatus (Risbec, 1952)}

Anastatoïdea elongata Risbec, 1952: 67, 69-71, fig. 17. Lectotype 9 designated by Gibson (1995: 286) (MNHN, examined by LF). Type locality: Madagascar, Bekily.

Anastatoidea elongata - Risbec 1958: 109 (keyed).

Tineobius (Progenitobius) elongatus - Gibson 1995: 284, 287, fig. 452.

\section{Tineobius (Progenitobius) mandrakae (Risbec, 1952)}

Cerambycobius mandrakae Risbec, 1952: 138-141. Lectotype $O$ designated by Fusu et al. (2015: 468) (MNHN, examined by LF). Type locality: Madagascar, Mandraka. 
Eupelmus mandrakae - Hedqvist 1970: 436 (catalogued).

Tineobius (Progenitobius) mandrakae - Fusu et al. 2015: 468-469, fig. 3A, C (type information).

Tineobius (Tineobius) Ashmead, 1896

Tineobius Ashmead, 1896: 14-15. Type species: Tineobius citri Ashmead, 1896 by original designation. Australeupelmus Girault, 1921: 3. Type species: Eupelmus multicolor Girault, 1915 by monotypy and original designation. Synonymy by Bouček (1988: 564).

Anastatoidea Gahan, 1927: 122. Type species: Anastatoidea brachartonae Gahan, 1927 by original designation. Synonymy by Bouček (1988: 564).

Anastatoïdea - Risbec 1952: 61, 66-71 (misspelling).

5. Tineobius (Tineobius) adamsi (Yoshimoto \& Ishii, 1965)

Anastatus adamsi Yoshimoto \& Ishii, 1965: 157, 159. Holotype 9 , by original designation (USNM 67527, not examined). Type locality: Caroline Island group: Ponape Island, Net Point.

Tineobius (Tineobius) adamsi - Gibson et al. 2012: 55.

6. Tineobius (Tineobius) afer (Ferrière, 1938) comb. nov.

Anastatoidea afra Ferrière, 1938: 52-53, 58. Syntypes 웅 (BMNH 5.943, examined by LF). Type locality: South West Africa [Namibia], Aus.

Anastatoïdea afra - Risbec 1952: 67 (keyed).

7. Tineobius (Tineobius) albopalpalis (Brues, 1907) comb. nov.

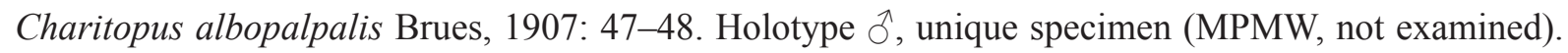
Type locality: South Africa, Cape Colony, Algoa Bay.

\section{Remark}

This new combination in Tineobius is proposed based on a personal communication by G.A.P. Gibson who examined the holotype. In the original description sex incorrectly stated as female.

8. Tineobius (Tineobius) beenleighi (Girault, 1926) stat. nov. [new subgeneric status]

Metapelma beenleighi Girault, 1926: 64. Holotype + , unique specimen (QMBA T.4210, not examined). Type locality: Australia, Beenleigh.

Metapelma beenleighi - Girault 1930a: 3 (repetition of original description). — Dahms 1983: 118 (information on type).

Anastatoidea beenleighi - Ferrière 1938: 45, 58 (keyed). — Risbec 1952: 66 (keyed).

Tineobius beenleighi - Bouček 1988: 565.

9. Tineobius (Tineobius) beharae (Risbec, 1952) comb. nov.

Anastatoïdea beharae Risbec, 1952: 67, 71-73. Syntypes 우 $\widehat{(M N H N, ~ e x a m i n e d ~ b y ~ L F) . ~ T y p e ~ l o c a l i t y: ~}$ Madagascar, Behara. 
10. Tineobius (Tineobius) brachartonae (Gahan, 1927) stat. nov. [new subgeneric status]

Anastatoidea brachartonae Gahan, 1927: 13-15. Holotype + , by original designation (USNM 29444, not examined). Type locality: Central Java.

Anastatoidea brachartonae - Ferrière 1936: 195 (catalogued, distribution). — Ferrière 1938: 48, 57 (keyed). - Risbec 1952: 67 (catalogued).

Tineobius brachartonae - Bouček 1988: 564.

11. Tineobius (Tineobius) capensis (Ferrière, 1938) comb. nov.

Anastatoidea capensis Ferrière, 1938: 53-54, 58. Syntypes $q$ (BMNH 5.945, examined by LF). Type locality: South Africa: Pondoland, Fort St. John.

Anastatoïdea capensis - Risbec 1952: 67, 68 (keyed, distribution).

12. Tineobius (Tineobius) citri Ashmead, 1896 stat. nov. [new subgeneric status]

Tineobius citri Ashmead, 1896: 15. Holotype ${ }^{\text {, }}$, unique specimen (USNM 3465, not examined). Type locality: Australia, New South Wales, Paramatta.

Tineobius citri - Bouček 1988: 565, figs 1004, 1005 (distribution, redescription).

13. Tineobius (Tineobius) columbi (Girault, 1923) stat. nov. [new subgeneric status]

Metapelma columbi Girault, 1923: 96-97. Holotype + , unique specimen (QMBA T.4215, not examined). Type locality: Australia, Queensland, Kuranda.

Metapelma columbi - Dahms 1983: 189 (type information).

Anastatoidea columbi - Gahan 1927: 15 (keyed). — Ferrière 1936: 195 (catalogued). — Ferrière 1938: 45, 57 (keyed, distribution).

Anastatoïdea colombi - Risbec 1952: 67 (misspelling).

Tineobius columbi - Bouček 1988: 565.

14. Tineobius (Tineobius) crassipes (Yoshimoto \& Ishii,1965)

Anastatus crassipes Yoshimoto \& Ishii, 1965: 156-158. Holotype 9 , by original designation (BPBM 3581, not examined). Type locality: Caroline Island group: Palau Island, Koror.

Tineobius (Tineobius) crassipes - Gibson et al. 2012: 56.

15. Tineobius (Tineobius) decoratus (Ferrière, 1938) stat. nov. [new subgeneric status]

Anastatoidea decorata Ferrière, 1938: 45-46, 59, fig. 5. Holotype + , by original designation (BMNH 5.940, examined by LF). Type locality: Fiji: Lautoka.

Anastatoïdea decorata - Risbec 1952: 67 (catalogued).

Tineobius decoratus - Bouček 1988: 565 (distribution). 
16. Tineobius (Tineobius) gonometae (Ferrière, 1938) comb. nov.

Anastatoidea gonometae Ferrière, 1938: 55-56, 58. Holotype + , unique specimen (BMNH 5.946, examined by LF). Type locality: South Africa: Transvaal, Louis Trichardt.

Anastatoïdea gonometae - Risbec 1952: 67 (keyed).

17. Tineobius (Tineobius) indicus (Ferrière, 1938) stat. nov. [new subgeneric status]

Anastatoidea indica Ferrière, 1938: 49-50, 58, fig. 6. Holotype $q$, unique specimen (BMNH type no. 5.937, examined by LF). Type locality: India [now Pakistan]: Punjab, Lyallpur.

Anastatoïdea indica - Risbec 1952: 66 (keyed).

Tineobius indicus - Bouček 1988: 565.

18. Tineobius (Tineobius) lamborni (Ferrière, 1938) comb. nov.

Anastatoidea lamborni Ferrière, 1938: 56, 58. Holotype $q$, unique specimen (BMNH type no. 5.947, examined by LF). Type locality: East Africa: Nyasaland, Kota-kotu.

Anastatoïdea lamborni - Risbec 1952: 67 (keyed).

19. Tineobius (Tineobius) longfellowi (Girault, 1923) stat. nov. [new subgeneric status]

Metapelma longfellowi Girault, 1923: 99. Holotype +, unique specimen (QMBA T.4209, not examined). Type locality: Australia: Kuranda.

Metapelma longfellowi - Girault 1926: 64. — Girault 1930a: 3 (compared with M. beenleighi). Dahms 1984: 764 (type information).

Anastatoidea longfellowi - Gahan 1927: 15 (keyed). — Ferrière 1938: 45, 57 (keyed). — Risbec 1952: 67 (catalogued).

Tineobius longfellowi - Bouček 1988: 565.

20. Tineobius (Tineobius) longicauda (Ferrière, 1938) stat. nov. [new subgeneric status]

Anastatoidea longicauda Ferrière, 1938: 49, 57. Holotype $q$, unique specimen (BMNH 5.938, examined by LF). Type locality: Siam: Bangkok.

Anastatoïdea longicauda - Risbec 1952: 67 (catalogued).

Tineobius longicauda - Bouček 1988: 565.

21. Tineobius (Tineobius) madagascariensis Fusu \& Ribes nom. nov.

Metapelma seyrigi Risbec, 1952: 63-66, fig. 16e, f. Holotype 9 , unique specimen (MNHN, examined by LF). Type locality: Madagascar: Ranomafana. Secondary homonym of Tineobius seyrigi (Ferrière, 1938).

22. Tineobius (Tineobius) montanus (Ferrière, 1938) comb. nov.

Anastatoidea montana Ferrière, 1938: 53, 58. Holotype + , unique specimen (BMNH 5.944, examined by LF). Type locality: South Africa: Cape Province, Katberg, 1200 m.

Anastatoïdea montana - Risbec 1952: 67 (keyed). 
23. Tineobius (Tineobius) multicolor (Girault, 1915) stat. nov. [new subgeneric status]

Eupelmus multicolor Girault, 1915: 10. Holotype $\odot$, unique specimen (QMBA Hy.2489, not examined). Type locality: Australia: Queensland, Gordonvale (Cairns).

Eupelmus multicolor - Dahms 1984: 835-836 (type information).

Australeupelmus multicolor - Girault 1921: 3.

Tineobius multicolor - Bouček 1988: 565 (distribution, stated as very close to Tineobius citri).

24. Tineobius (Tineobius) nassaui (Girault, 1933) stat. nov. [new subgeneric status]

Metapelma (Tineobius) nassaui Girault, 1933: 3. Holotype + , unique specimen (QMBA T.4211, not examined). Type locality: E. Australia [Brisbane according to label data].

Metapelma nassaui - Girault 1930b: 3 (nomen nudum, discovered by Dahms 1986: 321).

Metapelma nassaui - Dahms 1986: 321 (type locality data).

Tineobius nassaui - Bouček 1988: 565 (possible synonym of T. citri).

25. Tineobius (Tineobius) philippinensis (Ferrière, 1938) comb. nov.

Anastatoidea philippinensis Ferrière, 1938: 47-48, 58. Holotype + , unique specimen (BMNH 5.939, examined by LF). Type locality: Philippines: Mindanao, Zamboanga.

Anastatoïdea philippinensis - Risbec 1952: 66 (keyed). — Baltazar 1966: 129 (catalogued).

26. Tineobius (Tineobius) rufescens (Ferrière, 1938) comb. nov.

Anastatoidea rufescens Ferrière, 1938: 54-55, 59. Syntypes $ᄋ$ 우 (BMNH 5.948, examined by LF). Type locality: South Africa: Pondoland, Port St. John.

Anastatoïdea rufescens - Risbec 1952: 67, 68 (keyed, distribution)

27. Tineobius (Tineobius) salomonis (Ferrière, 1938) stat. nov. [new subgeneric status]

Anastatoidea salomonis Ferrière, 1938: 46-47, 59. Syntypes $q$ ㅇ (BMNH 5.941, examined by LF). Type locality: Solomon Island group: Tulagi and Guadalcanal.

Anastatoïdea salomonis - Risbec 1952: 67 (catalogued).

Tineobius salomonis - Bouček 1988: 565.

28. Tineobius (Tineobius) seyrigi (Ferrière, 1936) comb. nov.

Anastatoidea seyrigi Ferrière, 1936: 196-198, fig. 4. Syntypes † $^{\Uparrow}$ (BMNH 5.949, MNHN, examined by LF). Type locality: Madagascar, Bekily.

Anastatoidea seyrigi - Ferrière 1938: 52, 57 (keyed). — Risbec 1952: 66, 68 (keyed).

29. Tineobius (Tineobius) sidneyi (Girault, 1930) stat. nov. [new subgeneric status]

Metapelma Sidneyi Girault, 1930b: 3. Syntypes $q$ (ANIC, QMBA T.4214, not examined). Type locality: Australia, New South Wales, Sydney.

Metapelma sidneyi-Dahms 1986: 532 (type information). — Naumann et al. 1994: 72 (type information). Tineobius sidneyi-Bouček 1988: 565. 
30. Tineobius (Tineobius) superbus (Dodd, 1917) stat. nov. [new subgeneric status]

Metapelma superba Dodd, 1917:357-358. Holotype ${ }_{+}$, by original designation (QMBA, not examined). Type locality: Australia: Queensland, Townsville.

Metapelma superba - Girault 1923: 96, 99 (compared with T. columbi and T. longfellowi). Anastatoidea superba - Gahan 1927: 15 (keyed). — Ferrière 1938: 45, 57 (keyed). — Risbec 1952: 67 (catalogued).

Tineobius superbus - Bouček 1988: 566.

31. Tineobius (Tineobius) tamaricis Ribes \& Fusu sp. nov.

\section{Species described in Anastatoidea but excluded from Tineobius}

1. Eupelmus (Episolindelia) ambatomangae (Risbec, 1958) comb. nov.

Anastatoidea ambatomangae Risbec, 1958: 109, 112-114, fig. 2. Holotype + , unique specimen (MNHN, examined by LF). Type locality: Madagascar, Ambatomanga.

\section{Eupelmus (Episolindelia) pennisetae (Risbec, 1958)}

Anastatoidea pennisetae Risbec, 1958: 109-112, fig. 1. Syntypes 우스 (MNHN, examined by LF). Type locality: Madagascar: Terrain d'aviation de Majunga.

Eupelmus (Episolindelia) pennisetae - Fusu et al. 2015: 460 (type information).

\section{Discussion}

Tineobius is a diverse genus known from the Afrotropical, Oriental, and Australasian regions, including numerous undescribed species (Gibson 1995), but previously not recorded from the Palaearctic region. The newly described T. tamaricis sp. nov. from Spain represents the first species of the genus for the Palaearctic region. The most geographically close records of other Tineobius species are from Pakistan and the sub-Saharan Afrotropical region. The association of T. tamaricis sp. nov. with Parapodia sinaica, which is probably distributed over the entire Mediterranean area on several Tamarix species, implies that $T$. tamaricis sp. nov. could also be distributed over a larger area. The distribution range of several Tamarix species extends further into the Oriental and Afrotropical regions, mainly through Near East where P. sinaica galls were found to attack three different Tamarix species (Gerling et al. 1976). Via an Iranian, Ethiopian or Saharan path, there might be a connection between the populations of T. tamaricis sp. nov. in Spain with the tropical regions were Tineobius is more diverse. On the other hand, the localised distribution of T. tamaricis sp. nov., the fact that it was not collected before despite the Eupelmidae of Spain being well investigated (Askew \& Nieves-Aldrey 2000, 2004, 2006) and this being the sole species of Tineobius present in the Palaearctic region, might indicate that it is in fact an introduced species and not a local endemic. Also, the absence of any males reared over the four years might indicate it is a thelytokous species. If so, the likelihood of the species being introduced from elsewhere is further increased as there are examples of several eupelmid species in North America being introduced from other regions and with only females known (parthenogenesis favours the establishment of introduced species; Hoffman et al. 2008). This is the case of Balcha indica (Mani \& Kaul, 1973) (Gibson 2005), Eupelmus pini Taylor, 1927 (Gibson 2011; Gibson \& Fusu 2016), and Eupelmus vesicularis (Retzius, 1783) (s. lat., Fusu 2010). As exotic species of Tamarix are widely used as ornamental plants or for reforestation throughout Europe, T. tamaricis sp. nov. might have been introduced together with infested plants from Africa or Asia. 


\section{Acknowledgements}

The authors are grateful to G.A.P. Gibson (CNC, Ottawa, Canada) for information on the type material of some Tineobius species and to Peter Huemer (Tiroler Landesmuseen-Betriebsges, Innsbruck, Austria) for the verification of the identification of Parapodia sinaica. L. Fusu is thankful to R.R. Askew (Beeston, Cheshire, UK) for locating the unlabelled type series of T. tamaricis sp. nov. in ARPC and mailing it to AICF for curation and to two anonymous referees for their valuable comments. This study was supported by the research grant GI-2015-02, internal grants competition for young researchers, awarded by the Al.I. Cuza University to LF.

\section{References}

Al Khatib F., Fusu L., Cruaud A., Borowiec N., Rasplus J.-Y., Ris N. \& Delvare G. 2014. An integrative approach to species discrimination in the Eupelmus urozonus complex (Hymenoptera, Eupelmidae), with the description of 11 new species from the Western Palaearctic. Systematic Entomology 39 (4): 806-862. http://dx.doi.org/10.1111/syen.12089

Altschul S.F., Gish W., Miller W., Myers E.W. \& Lipman D.J. 1990. Basic local alignment search tool. Journal of Molecular Biology 215: 403-410. http://dx.doi.org/10.1016/S0022-2836(05)80360-2

Ashmead W.H. 1896. On the genera of the Eupelminae. Proceedings of the Entomological Society of Washington 4: 4-20.

Askew R.R. \& Nieves-Aldrey J.L. 2000. The genus Eupelmus Dalman, 1820 (Hymenoptera, Chalcidoidea, Eupelmidae) in peninsular Spain and the Canary Islands, with taxonomic notes and descriptions of new species. Graellsia 56: 49-61. http://dx.doi.org/10.3989/graellsia.2000.v56.i0.309

Askew R.R. \& Nieves-Aldrey J.L. 2004. Further observations on Eupelminae (Hymenoptera, Chalcidoidea, Eupelmidae) in the Iberian Peninsula and Canary Islands, including descriptions of new species. Graellsia 60 (1): 27-39. http://dx.doi.org/10.3989/graellsia.2004.v60.i1.191

Askew R.R. \& Nieves-Aldrey J.L. 2006. Calosotinae and Neanastatinae in the Iberian Peninsula and Canary Islands, with descriptions of new species and a supplementary note on Brasema Cameron, 1884 (Hymenoptera, Chalcidoidea, Eupelmidae). Graellsia 62 (1): 87-100. http://dx.doi.org/10.3989/ graellsia.2006.v62.i1.28

Baltazar C.R. 1966. A Catalogue of Philippine Hymenoptera (with a Bibliography, 1758-1963). Pacific Insects Monograph 8, Bishop Museum, Honolulu. http://dx.doi.org/10.5281/zenodo.23590

Bonfield J.K., Smith K.F. \& Staden R. 1995. A new DNA sequence assembly program. Nucleic Acids Research 24: 4992-4999. http://dx.doi.org/10.1093/nar/23.24.4992

Bouček Z. 1988. Australasian Chalcidoidea (Hymenoptera): A Biosystematic Revision of Genera of Fourteen Families, with a Reclassification of Species. CAB International, Cambrian News Ltd, Aberystwyth.

Brues C.T. 1907. New chalcid-flies from Cape Colony. Bulletin of the Wisconsin Natural History Society $5(1): 46-53$.

Casquet J., Thebaud C. \& Gillespie R.G. 2012. Chelex without boiling, a rapid and easy technique to obtain stable amplifiable DNA from small amounts of ethanol-stored spiders. Molecular Ecology Resources 12 (1): 136-41. http://dx.doi.org/10.1111/j.1755-0998.2011.03073.x

Dahms E.C. 1983. A Checklist of the Types of Australian Hymenoptera Described by Alexandre Aresene Girault: II. Preamble and Chalcidoidea Species A-E with Advisory Notes. Memoirs of the Queensland Museum 21 (1), Queensland Museum, Brisbane. 
Dahms E.C. 1984. A Checklist of the Types of Australian Hymenoptera Described by Alexandre Arsene Girault: III. Chalcidoidea Species F-M with Advisory Notes. Memoirs of the Queensland Museum 21 (3), Queensland Museum, Brisbane.

Dahms E.C. 1986. A Checklist of the Types of Australian Hymenoptera Described by Alexandre Arsene Girault: IV. Chalcidoidea Species N-Z and Genera with Advisory Notes plus Addenda and Corrigenda. Memoirs of the Queensland Museum 22 (3), Queensland Museum, Brisbane.

Dauphin P. \& Aniotsbehere J.C. 1994. Les Galles de France. Mémoires de la Société Linnéenne de Bordeaux 2, Société Linnéenne de Bordeaux, Bordeaux.

Dodd A.P. 1917. Records and descriptions of Australian Chalcidoidea. Transactions of the Royal Society of South Australia 41: 344-368.

Ferrière C. 1936. Note sur un nouvel Eupelmidae de Madagascar. In: Livre Jubilaire Prof. E.-L. Bourier: 195-198. Firmin-Didot et Cie, Paris.

Ferrière C. 1938. Eupelmides exotiques [Hymenopt. Chalcididae]. I. Les genres Metapelma Westw., Anastatoidea Gahan et Neanastatus Girault. Annales de la Société Entomologique de France 107: 2572.

Folmer O., Black M., Hoeh W., Lutz R. \& Vrijenhoek R. 1994. DNA primers for amplification of mitochondrial cytochrome c oxidase subunit I from diverse metazoan invertebrates. Molecular Marine Biology and Biotechnology 3: 294-299.

Fusu L. 2010. Species status of two colour morphs of Eupelmus vesicularis (Hymenoptera: Eupelmidae) as revealed by allozyme electrophoresis, morphometric and host preference data. Journal of Natural History 44: 1113-1129. http://dx.doi.org/10.1080/00222931003632773

Fusu L., Ebrahimi E., Siebold C. \& Villemant C. 2015. Revision of the Eupelmidae Walker, 1833 described by Jean Risbec. Part 1: The slide mounted specimens housed at the Muséum national d'Histoire naturelle in Paris. Zoosystema 37 (3): 457-480. http://dx.doi.org/10.5252/z2015n3a3

Gahan A.B. 1927. Miscellaneous descriptions of new parasitic Hymenoptera with some synonymical notes. Proceedings of the United States National Museum 71: 1-39. http://dx.doi.org/10.5479/ $\underline{\text { si.00963801.71-2676.1 }}$

Gebiola M., Bernardo U., Monti M.M., Navone P. \& Viggiani G. 2009. Pnigalio agraules (Walker) and Pnigalio mediterraneus Ferrière and Delucchi (Hymenoptera: Eulophidae): Two closely related valid species. Journal of Natural History 43: 2465-2480. http://dx.doi.org/10.1080/00222930903105088

Gebiola M., Bernardo U., Ribes A. \& Gibson G.A.P. 2015. An integrative study of Necremnus Thomson (Hymenoptera: Eulophidae) associated with invasive pests in Europe and North America: Taxonomic and ecological implications. Zoological Journal of the Linnean Society 173 (2): 352-423. http://dx.doi. org/10.1111/zoj.12210

Gerling D., Kugler J. \& Lupo A. 1976. The galls of insects and mites that occur on Tamarix spp. in Israel and the Sinai. Bollettino del Laboratorio di Entomologia Agraria "Filippo Silvestri" di Portici 33: 53-79.

Gibson G.A.P. 1995. Parasitic Wasps of the Subfamily Eupelminae: Classification and Revision of World Genera (Hymenoptera: Chalcidoidea: Eupelmidae). Memoirs on Entomology, International 5: 1-421. Associated Publishers, Gainesville.

Gibson G.A.P. 1997. Chapter 2. Morphology and terminology. In: Gibson G.A.P., Huber J.T. \& Woolley J.B. (eds) Annotated Keys to the Genera of Nearctic Chalcidoidea (Hymenoptera): 16-44. National Research Council, Ottawa. 
Gibson G.A.P. 2004. A new species of Oozetetes DeSantis (Hymenoptera: Chalcidoidea: Eupelmidae) attacking oothecae of Nyctibora acaciana Roth (Orthoptera: Blattellidae). Journal of Hymenoptera Research 13 (1): 13-23.

Gibson G.A.P. 2005. The world species of Balcha Walker (Hymenoptera: Chalcidoidea: Eupelmidae), parasitoids of wood-boring beetles. Zootaxa 1033: 1-62.

Gibson G.A.P. 2011. The species of Eupelmus (Eupelmus) Dalman and Eupelmus (Episolindelia) Girault (Hymenoptera: Eupelmidae) in North America north of Mexico. Zootaxa 2951: 1-97.

Gibson G.A.P. \& Fusu L. 2016. Revision of the Palaearctic species of Eupelmus (Eupelmus) Dalman (Hymenoptera: Chalcidoidea: Eupelmidae). Zootaxa 4081: 1-331. http://dx.doi.org/10.11646/ zootaxa.4081.1.1

Gibson G.A.P., Dewhurst C. \& Makai S. 2012. Nomenclatural changes in Anastatus Motschulsky and the description of Anastatus eurycanthae Gibson nov. sp. (Eupelmidae: Eupelminae), and egg parasitoid of Eurycantha calcarata Lucas (Phasmida: Phasmatidae) from Papua New Guinea. Zootaxa 3419: 5361 .

Girault A.A. 1915. Australian Hymenoptera Chalcidoidea - VII. The Family Encyrtidae with Descriptions of New Genera and Species. Memoirs of the Queensland Museum 4, Queensland Museum, Brisbane.

Girault A.A. 1921. New animals of Australia and old men of the Earth. Private publication, Brisbane.

Girault A.A. 1923. Remarkable chalcid-flies collected in northern Australia by A.P. Dodd (Hymenoptera). Insecutor Inscitiae Menstruus 11: 96-100.

Girault A.A. 1926. Notes and descriptions of Australian chalcid-flies (Hymenoptera). Insecutor Inscitiae Menstruus 14: 58-73.

Girault A.A. 1930a. New pests from Australia VII. Private publication, Brisbane.

Girault A.A. 1930b. New pests from Australia VIII. Private publication, Brisbane.

Girault A.A. 1933. Some Beauties Inhabitant Not of Commercial Boudoirs but of Nature's Bosom, Notably New Insects. Private publication, Brisbane.

Hebert P.D.N, Cywinska A., Ball S.L. \& de Waard J.R. 2003. Biological identifications through DNA barcodes. Proceedings of the Royal Society of London Series B 270: 313-322. http://dx.doi.org/10.1098/ $\underline{\mathrm{rspb} .2002 .2218}$

Hedqvist K.-J. 1970. Hymenoptera, Chalcidoidea, Eupelmidae. In: Hanstrom B., Brinck P. \& Rudebeck G. (eds) South African Animal Life. Results of the Lund University Expedition in 1950-1951 14: 402443. Swedish Natural Research Council, Stockholm.

Heraty J.M. \& Hawks D. 1998. Hexamethyldisilazane: A chemical alternative for drying insects. Entomological News 109: 369-374.

Hoffmann A.A., Reynolds K.T., Nash M.A. \& Weeks A.R. 2008. A high incidence of parthenogenesis in agricultural pests. Proceedings of the Royal Society B, Biological Sciences 275: 2473-2481. http:// dx.doi.org/10.1098/rspb.2010.2229

Houard C. 1912. Les Zoocécidies du Nord de l'Afrique. Annales de la Société Entomologique de France 81: 1-236.

Joannis J. 1912. Deux nouvelles espèces de Microlépidoptères cécidogènes de France. Bulletin de la Société Entomologique de France 14: 304-307.

Naumann I.D., Cardale J.C., Taylor R.W. \& MacDonald J. 1994. Type specimens of Australian Hymenoptera (Insecta) transferred from the Macleay Museum, University of Sydney, to the Australian 
National Insect Collection, Canberra. Proceedings of the Linnean Society of New South Wales 114 (2): 69-72.

Polaszek A., Ayshford T., Yahya B.E. \& Fusu L. 2014. Wallaceaphytis: an unusual new genus of parasitoid wasp (Hymenoptera: Aphelinidae) from Borneo. Journal of Natural History 48 (19-20): 1111-1123. http://dx.doi.org/10.1080/00222933.2013.852264

Rezaei A.A., Sadeghi S.E. \& Ali E. 2007. Biology of Parapodia sinaica (Lep.: Gelechiidae) in Qom province. Journal of Entomological Society of Iran 27 (1): 15-26.

Risbec J. 1952. Contribution à l'étude des chalcidoïdes de Madagascar. Mémoires de l'Institut Scientifique de Madagascar, Série E Entomologie 2, Institut de recherches scientifiques de la République malgache, Paris.

Risbec J. 1958. Eupelmidae de Madagascar. Le Naturaliste Malgache 10 (1-2): 97-114.

Yoder M.J., Mikó I., Seltmann K.C., Bertone M.A. \& Deans A.R. 2010. A gross anatomy ontology for Hymenoptera. PLoS ONE 5 (12): e15991. http://dx.doi.org/10.1371/journal.pone.0015991

Yoshimoto C.M. \& Ishii T. 1965. Insects of Micronesia: Hymenoptera Chalcidoidea: Eulophidae, Encyrtidae (part), Pteromalidae. Insects of Micronesia 19 (4): 109-178.

Manuscript received: 15 March 2016

Manuscript accepted: 23 May 2016

Published on: 24 January 2017

Topic editor: Gavin Broad

Desk editor: Charlotte Thionois, Charlotte Gérard \& Kristiaan Hoedemakers

Printed versions of all papers are also deposited in the libraries of the institutes that are members of the EJT consortium: Muséum national d'Histoire naturelle, Paris, France; Botanic Garden Meise, Belgium; Royal Museum for Central Africa, Tervuren, Belgium; Natural History Museum, London, United Kingdom; Royal Belgian Institute of Natural Sciences, Brussels, Belgium; Natural History Museum of Denmark, Copenhagen, Denmark; Naturalis Biodiversity Center, Leiden, the Netherlands. 